\title{
Understanding of Women in Indonesia: Motivation to Lead, Work-Family Conflict, and Ambition
}

\author{
Sumarto \\ Economic Faculity, University of Pembangunan Nasional "Veteran” East Java \\ Raya Rungkut Madya Street, Gunung Anyar, Surabaya 60294, Indonesia \\ Tel: 031-8706369 Email : sumarto_upnjatim@yahoo.com \\ Resi Permanasari \\ Economic Faculity, University of Pembangunan Nasional "Veteran” East Java \\ Raya Rungkut Madya Street, Gunung Anyar, Surabaya 60294, Indonesia \\ Tel: 031-8706369 Email : resipermanasari@ gmail.com
}

\author{
Accepted: August 16, 2013 Published: Sep 03, 2013 \\ Doi:10.5296/ijhrs.v3i3.4220 URL: http://dx.doi.org/10.5296/ijhrs.v3i3.4220
}

\begin{abstract}
There is a positive relationship between the high woman representation in public and the success of corruption and poverty eradication. This means that the role of women becomes very strategic along with the increase of woman representation in public region. In Indonesia, the problem is that woman representation is very low in public region, and from time to time it tends to decline. The low woman representation indicates that the motivation of women to lead is lower than men. It is estimated that work-family conflicts and ambition of women are the significant factors which is cause the low motivation of women to lead in Indonesia. The population consists of the civil servants of local governement in "Gerbangkertasusila" East Java. The data were collected by distributing questionares to respondents. Four relationship hypotheses were signifincantly proven. These are :1) the motivation of women to lead is lower than man; 2) the higher of women's work family conflict, the weaker the motivation of women to lead ; 3) the stronger motivation of women to lead, the stronger of women's work family conflicts; 4) the stronger the interaction between women's ambition and work-family conflict, the weaker the motivation of women to lead.
\end{abstract}

Keywords : Work-family conflict, Motivation to lead, Ambition

\section{Introduction}

Any nations that disrespect their woman will not be a great nation, either for now or in the future. One fundamental reason behind the drastic collapse of a nation is the disrespect 
against their woman. Indeed, woman is a manifestation of Mother Nature, and therefore, the rise of woman is also the rise of a nation (Vivekananda in Darwin, 2005). This expression values highly the dignity of woman.

A woman is symbolized as the sacred creature, culturally or socially. A woman is not important creature (the second human being), but merely a supplement (created from and for the interest of men). Both opinions are contradictive, and it is not surprised to say that the role of Indonesia women is in the uncertain internodes. Viewed from patriarchic culture perspective in Indonesia, if women enter the superiority realm of men, the family realm of women must still be their primary role. Therefore women play double (subjected to role conflict) because they must act as housewife but at same time, also be the seeker of subsistence.

Some findings of research challenge the bad perception of women within the life of community, including Indonesia. Swamy et al. (1999) admit that high representation of woman as the owner or manager of company can reduce the bribery rate. Many woman representatives in the parliament may also reduce the corruption rank of the country. It is consistent to Dollar et al. (2001) and Sung (2003) who explain that higher representative rate of woman in the government is related to lower level of corruption. Other study shows that higher participation of woman corresponds to higher level of community welfare and higher success level of poverty alleviation (Darwin, 2005). If it is integrated with corruption eradication and poverty alleviation, the presence and role of women may be very relevant and strategic which is corresponded with the increased woman representative within public realm.

\section{Lite rature Review}

Four reasons are asserted to answer why this study focuses on the role of women in public realm. These reasons are explained based on gender equality perspective where men are used the comparator. These reasons are:

- Low woman representation in the public realm, mainly in Indonesia (Darwin, 2005), and in the world (Kenworthy and Malami, 1999).

- The powerful strength of patriarchic culture in Indonesia, even legitimated by the nation (Darwin, 2005).

- Strategic role by women in public realm for corruption eradication and poverty alleviation (Swamy et al., 1999; Dollar et al., 2001; Sung, 2003; Darwin, 2005), mainly in Indonesia.

The research begins from the statement of Ebrahimi (1999) that low woman representation in public realm is the evidence of lower aspiration or lower motivation to become manager, or less motivated to pursue managerial careers (Clien et al., 1997). Both terms are identical with managerial role motivation or motivation to manage (Miner, 1993), or motivation to lead (Chan and Drasgow, 2001; Sanchez, 2003).

Findings of empirical researches from Allan and Nellen (1992), Bartol and Martin (1987), and Bartol et al. (1981) prove that women motivation to lead is lower than men. These three researches are conducted in America that is known with its western culture. Women struggle for gender similarity (gender equally) through their feminism movement. In contrast, research by Chen et al. (1997), Ebrahimi (1999), and Ebrahimi et al. (2001) find that there is no 
difference in motivation to lead between women and men. These three researches are carried out in Asia (China and Hong Kong) which is famous with eastern culture. Interestingly, the women live within patriarchic culture environment, but still with the demand of gender equality.

Based on the perspective of the dichotomy of west and east cultures, with each characteristic of gender justice (equally and equality), it is reasonable to find a confusing result of research about the motivation to lead between women and men. However, it may be still attractive to examine the degree of motivation to lead between women and men in Indonesia (Donnell and Hall, 1980; Lord et al., 1986; Pajares, 1996; Chen et al., 1997; Chan and Drasgow, 2001; Webb, 2003; Sanches, 2003; Ebrahimi et al., 2005). It needs to be sure whether the result of the research so far is consistent with Allan and Nellen (1992), Bartol and Marlin (1987), and Bartol et al. (1981), that motivation of men to lead is higher than that of women, or whether the result is equaled to Ebrahimi (1999;2001), Chen et al. (1997), and Maner (1993), that motivation of men to lead is similar to women.

In comparing current researches and previous researches, the difference remains within factors influencing or being antecedent and outcome of the motivation to lead itself, which involves: the increased work-family conflict due to the increased motivation of women to lead (Greenhaus and Kopelman, 1981; Greenhaus and Beutell, 1985; Rachman, 1998), low motivation of women to lead because of the increased work-family conflict (Ragins and Sundstrom, 1989; Gutek et al., 1991; Boles, 2001; Elloy and Smith, 2003), and the increased motivation of women to lead due to their ambition and work-family conflict (Howard and Bray, 1988; Korabik and Rosin, 1995; Kirchmeyer,1998; Metz, 2004; Mathur-Helrn, 2006). These variables must be researched.

Some other findings show that women leadership is better than men. Within transformational leadership style, emotional intelligence of women is better than men (Porterfield and Kleiner, 2005). Stanford asserts that the feminism characteristic of women brings privilege to women leader, such as communication skill, superior arbitrator, and problem solving with soft approach (Appelbaum and Miller, 2003). Many researches confirm the privilege of women leadership, but some facts also indicate low woman representation in the leadership/management. Low women representation signs the weaker managerial role motivation or the weaker motivation of women to lead (Powell and Butterfield, 1994; Chen et al., 1997).

Research about the difference of men and women in the managerial role motivation is very few. A synthesis of some researches about managerial role motivation highlights that motivation of women to lead is lower than men. Kloot (2004) asks "why women do not show good leadership, or always suffer from leadership distortion?" Some opinions are quoted by Kloot (2004), such as:

- Sinclair: Within the employment world, motivation of men is initiated by the demand of achievement, while motivation of women is based on the demand of affiliation.

- Gilligant: There is a difference of the experience between women and men in making decision of children care. This difference causes different skills and traits when they enter the employment world. 
- Chung and Monroe: Men have interest more on competitive success, while women are focusing on doing a job well. Men concern less with human relation and seem more aggressive. Men can be tolerant to ethical misbehavior while women are reverse.

- Shakeshaft : Traditionally, characteristics such as firm, competitive, work-oriented, and aggressive, are important elements in management. Women often apply relational and participatory skills in management, and prefer avoiding conflict and using collaborative strategy.

Kloot (2004) and Hayes et al. (2004) insist that these four conditions as certain the lower position of women than men in leadership and management. Traditional culture perspective of Indonesia women is never touched with rigidity, powerfulness, or firmness that are the key elements of power or leadership. Therefore, Indonesia women are usually lack of managerial role motivation than men.

Work and family are two most important aspects of workers' life. Between these two, there is a conflict of interest. Conflict of work responsibility and family responsibility, and its effect on workers, are the is sue which is greatly attended in the popular and scientific publications (Boles et al., 2001). Williams and Alliger (1994) remind that it must be given serious attention because women workers have conflict potential against their family life, which is in turn, influencing performance.

Work-family conflict suffered by the family women is obvious when they must balance the demand of work and the demand of family life. Failure to balance both will produce work-family conflict. This conflict is a combination between work overload, role conflict, and role ambiguity (Elloy and Smith, 2003). The conflict of work responsibility and family responsibility is classified as the causal factor of absenteeism, low job satisfaction, and low motivation (including motivation to lead). These three causes are related to permanent withdrawal behavior and turnover (Abbott el al., 1998). It means that the decision of women to leave the work for the family issue is prioritized more than the work itself (Gutek et al., 1991).

For women, higher career progress is higher tension of work-family conflict, and it makes them far away from the family (Butler, 2004). Career progress always involves higher motivation to pursue the career, higher responsibility (time and mind) at work, and lower attention (time and mind) for family. In general, women give interest more to family than work (Gutek et al., 1991). Women can sacrifice their career progress to limit the stress (Nieva, 1985) such that women may be less motivated to lead than men (Donnell and Hall, 1980).

Within the discussion of work-family conflict, and as related to the motivation to lead, it is concluded that work-family conflict has negative impact on motivation to lead. Higher motivation to lead means that the allocation of timing is given for work, but causing higher tension of work-family conflict. it can be said that there is a bi-directional relationship between work-family conflict and motivation to lead.

Work-family conflict may have less negative influence on motivation to lead if women or men have strong ambition to be a leader. Mathur and Helm (2006) find that ambition is one important characteristic from $65 \%$ samples for the promotion of career success of women 
into the position oftop management. Previous research expresses that the ambition is positively related to work commitment of women (Korahik and Rosin, 1995). Therefore, ambition is greatly related to career success of women than of men (Kirchmeyer, 1998).

Metz (2004) reveals that women with ambition will work harder than those without ambition to increase their self quality (education, training and development) to prepare their selves for managerial position. Ambition is a dimension of personality but without direct relation with career success (managerial advancement) through education, training and development as the component of human capital (Metz, 2004). Motivation to obtain something may be stronger when the ambition pushes it forward. Women with ambition can work longer and it signifies the higher commitment to the organization than those without ambition (Korabik and Rosin, 1995).

Ambition is closely related to motivation to lead and work-family conflict. It is then said that the higher ambition, the stronger motivation to lead. If the strength of ambition interacts with work-family conflict, it can be said that ambition strength can attenuate the negative effect of work-family conflict on motivation to lead. It is shown in conceptual framework of research in Figure 1.

\section{Figure 1. Research Conceptual Frame work}

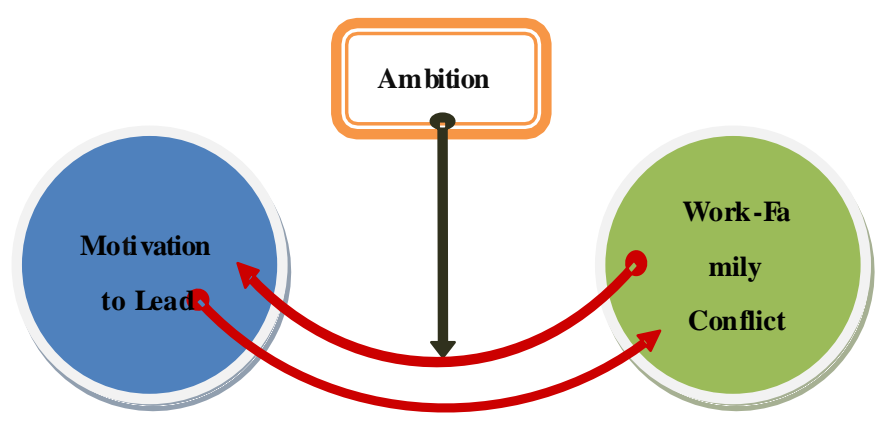

\section{Hypotheses of Research}

Lower woman representation in public realm triggers the research on the comparison of motivation to lead between women and men in Indonesia context, and its relationship with their ambition and work-family conflict. Based on review of literature and conceptual framework, it is hypothesized that:

- Motivation of women to lead is lower than men.

- The higher of women's work family conflict, the weaker the motivation of women to lead.

- The stronger motivation of women to lead, the stronger of women's work family conflicts.

- The stronger the interaction between women's ambition and work-family conflict, the weaker the motivation of women to lead.

\section{Methodology}

Research object is some second-tier local governments in East Java Province which belong to 


\section{Macrothink}

International Journal of Human Resource Studies

ISSN 2162-3058

2013, Vol. 3, No. 3

a major region of Gerbangkertosusila. The unit of analysis is the civil servants, women and men, in Rank III (IIIa, IIIb, IIIc, IIId) in this region. Sampling technique is probability sampling because the number of population is known (population access), which is 30,801 civil servants. Sampling technique of stratified random sampling is one type of probability sampling technique. The sample is 200 civil servants (100 men and 100 women) in Rank III. Result of the questionnaire filling is checked and only 117 (60 women and 57 men) are used for analysis.

\section{Finding}

Result of analysis of variance with dummy variables is shown in Table 2. Result of analysis with Structural Equation Modeling is indicated in Table 3. The result of Correlation Analysis is shown in Table 4.

Table 2. Result of The Analysis of Difference between Men and Women

\begin{tabular}{|l|l|l|ll|}
\hline $\begin{array}{c}\text { Dependent } \\
\text { Variable }\end{array}$ & $\begin{array}{c}\text { Men } \\
\text { Estimation }\end{array}$ & $\begin{array}{c}\text { Women } \\
\text { Estimation }\end{array}$ & Conclusion \\
\hline Work-family & 17.755 & 18.217 & Women & $>$ \\
conflict & 25.456 & 24.000 & Men & \\
Motivation to lead & 3.532 & 3.450 & Women & $<$ \\
Ambition & & & Men & \\
& & & Women & $=$ \\
& & & Men & \\
\hline
\end{tabular}


Table 3. Result of Testing of the Direct Effect Hypothesis

\begin{tabular}{|c|c|c|c|c|}
\hline $\begin{array}{c}\text { Independent } \\
\text { Variable }\end{array}$ & $\rightarrow$ Dependent Variable & $\begin{array}{l}\text { Standardiz } \\
\text { ed } \\
\text { Estimation }\end{array}$ & $\begin{array}{l}\mathrm{p}-\mathrm{Va} \\
\text { lue }\end{array}$ & Note \\
\hline & Woman & & & \\
\hline $\begin{array}{r}\text { Work-family } \\
\text { conflict }\end{array}$ & $\rightarrow$ Motivation to lead & -0.781 & $*$ & $\begin{array}{c}\text { Significa } \\
\mathrm{nt}\end{array}$ \\
\hline Ambition & $\rightarrow$ Motivation to lead & 0.142 & $* * *$ & $\begin{array}{c}\text { Significa } \\
\mathrm{nt}\end{array}$ \\
\hline WFC \& Ambition & $\rightarrow$ Motivation to lead & 0.172 & $* * *$ & $\begin{array}{c}\text { Significa } \\
\mathrm{nt}\end{array}$ \\
\hline Motivation to lead & $\begin{aligned} & \text { Work-family } \\
\rightarrow & \text { conflict }\end{aligned}$ & 0.690 & $* * *$ & $\begin{array}{c}\text { Significa } \\
\mathrm{nt}\end{array}$ \\
\hline & Men & & & \\
\hline $\begin{array}{r}\text { Work-family } \\
\text { conflict }\end{array}$ & $\rightarrow$ Motivation to lead & -0.620 & $* * *$ & $\begin{array}{c}\text { Significa } \\
\mathrm{nt}\end{array}$ \\
\hline Ambition & $\rightarrow$ Motivation to lead & 0.336 & $* * *$ & $\begin{array}{c}\text { Significa } \\
\mathrm{nt}\end{array}$ \\
\hline WFC \& Ambition & $\rightarrow$ Motivation to lead & 0.343 & $* * *$ & $\begin{array}{c}\text { Significa } \\
\mathrm{nt}\end{array}$ \\
\hline Motivation to lead & $\begin{array}{l}\rightarrow \text { Work-family } \\
\text { conflict }\end{array}$ & 0.548 & $* * *$ & $\begin{array}{c}\text { Significa } \\
\mathrm{nt}\end{array}$ \\
\hline
\end{tabular}

Note: $* * *=\mathrm{p}$-value $\leq 0.001$

WFC : Work-family conflict

Table 4. Correlation Across Variables

\begin{tabular}{|r|l|l|l|l|l|l|l|l|}
\hline & WFC & ML & AB & AG & EB & RK & ALC & NC \\
\hline WF & 1 & & & & & & & \\
CL & -0.265 & 1 & & & & & & \\
& $*$ & & & & & & & \\
AB & 0.326 & 0.352 & 1 & & & & & \\
& $*$ & $*$ & & & & & & \\
AG & -0.237 & 0.399 & 0.359 & 1 & & & & \\
& $*$ & $*$ & $*$ & & & & & \\
EB & 0.316 & 0.307 & 0.401 & 0.049 & 1 & & & \\
RK & $*$ & $*$ & $*$ & & & & & \\
& -0.372 & 0.315 & 0.311 & 0.230 & 0.07 & 1 & & \\
ALC & -0.337 & 0.087 & 0.079 & 0.011 & 0.01 & 0.00 & 1 & \\
& $*$ & & & & 3 & 9 & & \\
NC & 0.144 & 0.010 & 0.091 & 0.193 & 0.01 & 0.07 & 0.04 & 1 \\
& $*$ & & & $*$ & 8 & 8 & 5 & \\
\hline
\end{tabular}

Note: $*$ p-value $\leq 0.05$ 
WFC : Work-family conflict ML : Motivation to lead

AB : Ambition AG : Age

$\mathrm{EB} \quad$ : Education background $\quad \mathrm{RK} \quad$ : Rank

ALC : Age of the last child NC : Number of child

\section{Discussion}

\subsection{Motivation to Lead among Women and Men}

Empirical evidences indicate the presence of gender-based differences in levels of managerial motivation based on Score of MSCS-H. It means that motivation of women to lead than that of men. It is shortly explained as follows. Gender imbalance in the family responsibility is a constraint against woman representation in management (Davidson and Burke, 2004; Wirth, 2001). Many women consider their responsibility in family is a constraint against their managerial career (Liff and Ward; 2001; Metz and Tharenou, 2001). Women do not have interest or may have less motivation to lead because they are culturally positioned to take care of the family (Dolecheck and Dolecheck, 1987). The preservation of primary function of women is constraining them from pursuing managerial career and reducing their motivation to lead. Therefore, motivation of women to lead is lower than that of men.

Negative attitude of men colleagues against women manager is triggered by considered of women as "glass ceiling effect" which only prohibiting men from occupying managerial position (Ng's, 1993). However, the strong feminist perception within employment world is that men are only giving "glass ceiling effect" against women and therefore, women have lower motivation to lead than men.

\subsection{Work-Family Conflict and Motivation to Lead}

Empirical evidences have shown that work-family conflict among women and men is giving negative influence on motivation to lead. It means that the stronger work-family conflict, the lower motivation to lead. The negative impact of work-family conflict on motivation to lead is greater among women than men. This finding is shortly elaborated as follows:

- The work to serve husband and to care children is still the domain of responsibility of women (Shelton and John, 1996).

- Women are suffered more from stronger relationship between family involvement and work-family conflict than men (Greenhaus, 1989; Rothbard, 2001).

- Maternal mandatory is stronger perceived within Asia culture, including Indonesia. Therefore, women professional with family is finding more difficulties than men in balancing between work and family. Their work-family conflict, as consequence, is greater (Greenhaus, 1989).

- Women experience greater work-family conflict than men when they try to balance dual roles as worker and as the keeper of family (Frone, et al., 1992; Kim and Ling, 2001).

- Commitment to primary role may motivate women to reject labor mobility because it may hinder their responsibility in taking care of family (Carnicer et al., 2003).

- Women manager and women professional consider maternal factor as preventing their career development (Carnicer et al., 2004).

Indeed, the higher work-family conflict, the lower motivation of women to lead than that of 
men. This finding supports the greater tension of work-family conflict among women than men. It is consistent to the analysis of the difference of work-family conflict. Interestingly, it also indicates that women with work and family still have high commitment and consistency to do their primary role.

\subsection{Motivation to Lead and Work-Family Conflict}

Empirical evidences have indicated that motivation to lead among women and men is positively influencing work-family conflict. It means that the stronger motivation to lead, the stronger work-family conflict. The positive impact of motivation to lead on work-family conflict is greater among women than men. Brief expression of this finding is as follows:

- Husband/family with wife/mother in managerial/professional position experiences more intensive work-family conflict than those without wife/mother in managerial/professional position (Greenhaus and Kopelman, 1981).

- The less balance of two roles (work-family) only leads to increase the pressure or stress rate of family and work (Greenhaus and Beutell, 1985).

- For women with role within public realm, role conflict occurs due to their double roles. Work-family conflict may emerge from the combination of work overload, role conflict and role ambiguity (Elloy and Smith, 2003).

- Women with work and family still have high commitment and consistency to do their primary role (work-family conflict of women > work-family conflict of men)

Career progress of women because of their greater motivation to lead will require greater responsibility (time, mind, attendance) to the work. The demand of this responsibility will reduce their attention (time, mind, attendance) that should be given to the family (husband and children). It means that the higher motivation to lead, the higher work-family conflict of women than of men.

\subsection{Interaction of Ambition and Work-Family Conflict against Motivation to Lead}

The interaction between ambition and work-family conflict has positive impact on motivation to lead. It means that ambition can change the impact of work-family conflict on motivation to lead. For women, this impact is smaller than for men. It can be shortly expressed as follows:

- People with ambition will try harder and stronger to achieve something (motivation to lead) they want to than those without ambition or with weak ambition (Metz, 2004).

- Women with ambition can work longer and it signifies the higher commitment to the organization than those without ambition (Korabik and Rosin, 1995).

- Hard work is aimed to increase their self quality (education, training and development) to prepare their selves for managerial position (Ischinger, 2006).

- Ambition is more related to career success of women than that of men (Kirchmeyer, 1998).

- Ambition is one important characteristic from $65 \%$ samples for the promotion of career success of women into the position of top management (Mathur-Helm, 2006).

- Ambition is a dimension of personality but without direct relation with career success (managerial advancement) through education, training and development as the component of human capital (Metz, 2004). 
In preserving their primary function, women with strong ambition cannot sacrifice their family although they have high commitment to organization. Women with strong ambition are women with smartness (smart women). It is shown by their capability to keep the balance between organizational interest and family interest. It means that women can suppress the negative effect of work-family conflict. Family is therefore used as the main push for their motivation to lead. Therefore, it is said that the higher ambition, the lower negative effect of work-family conflict on motivation to lead among women than men.

\section{Conclusion and Suggestion}

\subsection{Conclusion}

Although Indonesia is included within moderate feminine culture dimension (Hofstede, 1980), empirical evidence shows that work environment tends to be masculine culture. Within masculine culture (patriarchic culture), women suffer from greater resistance from their men colleagues (Hofstede, 1995). This resistance may take a form of "glass ceiling" as the barrier against upward mobility of women career. Therefore, the motivation of women to lead is lower than that of men.

The stronger patriarchic (masculine) culture in work environment forces women to be consistent with their traditional role. This forced consistency to traditional role motivates women to reject upward mobility (Carnicer, 2003) and they give more interest to family than work (Gutek et al., 1991). If role conflict occurs, women can sacrifice their career progress, and as a result, women have lower motivation to lead than men (Donnell and Hall, 1980; Ragins and Sundstrom, 1989). It is then asserted that the higher work-family conflict, the lower motivation of women to lead than that of men.

When women have motivation to lead, role conflict happens. Failure to balance traditional role and work world is causing such conflict. Work-family conflict may occur from this, especially from the combination between work overload, role conflict and role ambiguity (Elloy and Smith, 2003). It can be then determined that the higher motivation to lead, the higher work-family conflict among women than men.

Ambition is closely related with career success of women than that of men (Kirchmeyer, 1998). For women with ambition, any barriers will be penetrated as long as they believe that something is achievable (being smart women). Strong ambition (women ambition = men ambition) can change negative impact of work-family conflict on motivation to lead. Negative impact may reduce and change into positive. Therefore, it can be sure that the higher ambition, the lower negative effect of work-family conflict on motivation of women to lead than that of men.

The positive moderation effect of ambition into the relationship between work-family conflict and motivation to lead is lower among women than men. Empirical evidences indicate that the ambition rate of women and men is similar. Why is that?

First, empirical evidences show that work environment of respondents (second-tier local government) is often oriented toward masculine culture. Within masculine culture environment, women experience greater resistance from men colleagues (Hofstede, 1995). A form of this resistance is "glass ceiling" element which is constraining upward mobility of 
women career.

Second, strong masculine culture within work environment of respondents forces women to be consistent to their traditional role. Their consistency to their traditional role motivates women to reject upward mobility (Carnicer, 2003). They give more interest to family than work (Gutek et al., 1991). If there is role conflict, women sacrifice their career progress, and consequently, women have lower motivation to lead than men (Donnell and Hall, 1980; Ragins and Sund strom, 1989).

Third, theoretically, Hofstede (2007) explains that men are characterized with some attributes such as give more emphases on career success, more ambitious, firm, competitive, life-for-work, consider women as house keeper, and high achievement. Women give more priorities to life quality, close interpersonal relationship, care for the weak, work-for-life, consider women and men as the keeper of family, and adequate achievement.

\subsection{Suggestions}

Empirical evidences so far confirm that motivation of women to lead is lower than that of men. It underscores the phenomenon of low woman representation than man representation within public realm of Indonesia. It means that the finding can be generalized that motivation of women to lead is lower than that of men. As a result, woman representation within public realm is lower than man representation.

Based on this finding, the barrier of motivation of women to lead is work-family conflict (Greenhaus and Beutell, 1985), and the stronger perception of glass ceiling only empowers the resistance against women within masculine culture (Hofstede, 1995) and sharpens the difference of life perception between masculine and feminine (Hofstede, 2007).

Work-family conflict suffered by women that is hindering their motivation to lead should be reduced by the current leader by giving attention to the characteristic of such work-family conflict. The most dominant work-family conflict for women respondents is the anxiety of divorce. For men respondent, the most dominant work-family conflict is the anxiety of losing father figure for children. Although work-family conflict is giving negative impact on motivation of men to lead, the rate is still less than that of women.

A little work-family conflict (threat of divorce) and perception of glass ceiling will always accompany women with work and family. It surely negatively influences a number of work-attitudes and behavior at work place, and in turn, it may reduce performance. To reduce negative impact, organization and local government should deliver some performance-based regulations and policies which are family-friendly and fair-play. These regulations and policies are consistent to gender characteristic among women in civil servants, mainly to their primary role (gender sensitive policy).

Related to motivation to lead, women respondents admit that a woman with work and family who has motivation to lead should have the most dominant attribute, which is the desire to perform routine administrative functions. For men respondents, the most dominant attribute is to have competence or the desire to be distinct and different. Other finding also confirms that besides this dominant attribute, the desire to compete (masculine culture) is still considered as 
important for women and men with work and family who have motivation to lead.

To increase the motivation to lead, organizational leader and the local government must give specific concern to women. The quality of human resource can be improved through education, training and development. For women, it is important to increase their administrative ability and skill, but for men, it is useful to increase their competence. Through the increase of each ability and skill, fair competition must be created.

The policy of increasing human resource quality through education, training \& development will grow the enthusiasm and ambition to produce the motivation of women to lead to be similar with that of men. Therefore, no more negative perceptions should be given against women such as perceiving that employment world is the world of men, men should be the number first, and women must be the next number.

\section{References}

Abbott, J., Cieri, H.D. and Iverson, R.D. 1998. Costing turn-over: Implication of work-family conflict at management level, Asia Pacific Journal of Human Resource . 36(1):25-43.

Allan, P. and Nellen, E.H. 1992. The motivation to manage : Differences between college students of business according to race, The Mid - Atlantic Journal of Business. 28(3):273-280.

Appelbaum, S.H., Audet, L. and Miller, J.C. 2003. Gender and leadership? Leadership and gender? A journey through the landscape of theories, Leadership \& Organization Development Journal. 24(1/2):43-51.

Bartol, M.K., Anderson, C.R. and Schreier, C.E. 1981. Sex and ethnic effects on motivation to manage among college business students, Journal of Applied Psychology. 66(1):40-44.

Bartol, M.K. and Martin, D.C.1987. Managerial motovation among MBA student: A longitud inal assesment. Journal of Occupational Psychological. 60:1-12

Boles, J.S., Howard, W.G. and Donofrio, H.H. 2001. An investigation into inter-realtionships of work-family conflict, family-work conflict and work satisfaction, Journal of Managerial Issue. 13(3): 376-390.

Carnicer, M.P., Sanchez, A.M., Perez, M.P. and Jimenez, M.J.V.,2003, Gender difference mobility : Analysis of job and work family factors, Women in Management Review. 18(4): 199-219.

Carnicer, M.P., Sanchez, A.M., Perez, M.P. and Jimenez, M.J.V. 2004. Work-family conflict in a southern European country: The influence of job-related and non-related factors, Journal of Managerial Psychology. 19(5):466-489.

Chan, K.Y. and Drasgow, F. 2001. Toward a theory of individual differences and leadership: Understanding the motivation to lead, Journal of Applied Psychologl. 86:481-498.

Chen, C.C., Yu, K.C. and Miner, J.B. 1997. Motivation to manage : A study of women in 
Chinese state-owned enterprises, The Journal of Applied Behavioral Science. 33(2):160-173.

Darwin, M.M. 2005. Negara Dan Perempuan, : Reorientasi Kebijakan Publik, Penerbit Media Wacana, Yogyakarta.

Davidson, M.J. and Burke, R.J. 2004. Women in Management World-Wide: Facts, Figures and Analysis, Ashgate Publishing Limited, Aldershot.

Dolecheck, M.M. and Dolecheck, C.C. 1987. Discrimination of women in the work place, Human Resources Journal. 3(1):37-44.

Dollar, D., Fisrnan, R. and Gatti, R. 2001. Are women really the "fairer- sex? Corruption and women in government, Journal of Economic Behavior \& Organization. (46):29-43.

Donnell, S.M. and Hall, J. 1980. Men and women as managers : A significant case of no significant difference, Organizational Dynamic. 8(4):60-77.

Ebrahimi, B.P. 1999. Managerial motivation and gender roles : A study of females and males in Hong Kong, Women in Management Review. 14(2):44-56.

Ebrahimi, B.P., Petrick, J.A. and Young, S.A. 2005. Managerial role motivation and role-related ethical orientation in Hong Kong, Journal of Business Ethics 60:29-45.

Elloy, D.F. and Smith, C.R. 2003. Patterns of stress, work-family conflict, role conflict, role ambiguity and overload among dual-career and single-career couples an Australian study, Cross Cultural Management. 10:55-66.

Greenhaus, J.H. and Kopelman, R.E. 1981. Conflict between work and nonwork roles: Implications for the career planning process, Human Resource Planning. 4(1):1-10.

Greenhaus, J.H. and Beutell, N.J. 1985. Source of conflict between work and family roles. Academy of Management Review. 10:76-88.

Gutek. B.A., Searle, S. and Klepa, L.1991. Rational versus gender role explanations for work- family conflict, Journal of Applied Psychology. 76(4):560-568.

Hayes, J., Allinson, C.W. and Armstrong, S.J. 2004. Intuition, women managers and gendered stereotypes, Personnel Review. 33(4):403-417.

Hofstede, G.H. 1995. Gender stereotypes and partner preferences of Asian women in masculine and feminine cultures, Journal of Cross-Cultural Psychology. 27(5):533-546.

Hofstede, G.H. 2007. Asian management in the 21" century, Asia Pasific Journal Management. 24:411-420.

Howard, A. and Bray, D.W. 1988. Managerial Lives in Transition, Guilford Press. New York.

lschinger, B. 2006. Education raising ambitions, Organization for Economic Cooperation and Development. The OECD Observer 257:13-14.

Korabik, K. and Rosin, H.M. 1995. The impact of children on women's career behavior and organizational commitment, Human Resource Management. 34(4):513-528. 
Kenworthy, L. and Malami, M. 1999. Gender inequality in political representation: A worldwide comparative analysis, Social Forces. 78(1):235-267.

Kim, J. and Ling, C. 2001. Work-family conflict of women entrepreneurs in Singapore, Women in Management Review. 16(5):204-221.

Kirchmeyer, C. 1998. Determinants of managerial career success: Evidence and explanation of male-female differences, Journal of Management. 24:673-692.

Kloot, L. 2004. Women and leadership in universities: A case study of women academic managers, The International Journal of Public Sector Management. 17(6):470-485.

Liff, S. and Ward, K. 2001. Distorted views through the glass ceiling, Gender, Work, and Organization. 8(1):9-36.

Mathur-Helm, B. 2006. Women and the glass ceiling in South African Banks: An illusion or reality? Women in Management Review. 21(4):311-326.

Metz, I. and Tharenou, P. 2001. Women's career advancement: The relative contribution of human and social capital, Gender \& Organization Management. 26:312-42.

Metz, I. 2004. Do personality traits indirectly affect women's advancement? Journal of Manefeial Psychology. 19(7):695-707.

Miner, J.B. 1993. Role Motivation Theories, Routledge, London.

Ng's, C. 1993. Attitudes toward women as managers in some male-dominated professions in Hong Kong, in Orhant, M. and Westwood, R.I. (Eds.), Proceedings of the First International Conference on Women in Management in Asia, University of Hong Kong, Chinese.

Nieva, V.F. 1985. Work and family linkages, in women and work: An annual review. in L. Garwood, A.H. Strornberg, and B. Gutek, (Eds.) Vol. 1, Sage Publications Inc. CA : Beverly Hills.

Pajares, F. 1996. Self-efficacy beliefs in academic settings. Review of Educational Research. 66:543-579.

Porterfield, J. and Kleiner, B.H. 2005. A new era: Women and leadership, Equal Opportunities International. 24(5/6):49-56.

Powell, G.N. and Butterfield, D.A. 1994. Investigating the glass ceilipg phenomenon: An empirical study of actual promotions to top management, Academy of Management Journal. 37(1):68-86.

Ragins, B.R. and Sundstrom, E. 1989. Gender and power in organizations: A longitudinal perspective, American Psychological Association. 105(1):51-88.

Rothbard, N. 2001. Enriching or depleting? The dynamics of engagement in work and family roles, Administrative Science Quarterly. 46:655-84.

Russell, M. and Cooper, M.L. 1992. Antecedents and outcomes of work-family conflict: Testing a model of the work-family interface, Journal of Applied Psychology. 
77(1):65-78

Sanchez, S.A. 2003. The relationship among motivation to lead, cognitive ability, and personality. Non Publication Dissertation, Our Lady of The Lake University. http://proquest.umi.com/dissertations/preview al1/3096518. Feb.22. 2007.

Sung, H.E. 2003. Fairer sex or fairer system? Gender and corruptie revisited, Social Forces. 82(2):703-723.

Swamy, A., Azfar, O., Knack, S. and Lee, Y. 1999. Gender and corruption, Working Paper \#232, www.ssrn.com. SSRN-id260062.April. 24. 2006.

Webb, M. 2003. Motivation to Lead and Academic Achievement, International Leadership Studies Conference. School of Leadership Studies. Regent University.

Williams, K.J. and Alliger, GM. 1994. Role stressors, mood spillover, and perceptions of work-family conflict in employed parents, Academy of Management Journal. $37(4): 837-868$.

Wirth, L. 2001. Breaking Through the Glass Ceiling, ILO, Geneva. 